IZA DP No. 5618

Incentives and Cooperation in Firms:

Field Evidence

Johannes Berger

Claus Herbertz

Dirk Sliwka

April 2011 


\title{
Incentives and Cooperation in Firms: Field Evidence
}

\author{
Johannes Berger \\ University of Cologne \\ Claus Herbertz \\ University of Cologne \\ Dirk Sliwka \\ University of Cologne \\ and IZA
}

\section{Discussion Paper No. 5618 \\ April 2011}

\author{
IZA \\ P.O. Box 7240 \\ 53072 Bonn \\ Germany \\ Phone: +49-228-3894-0 \\ Fax: +49-228-3894-180 \\ E-mail: iza@iza.org
}

\begin{abstract}
Any opinions expressed here are those of the author(s) and not those of IZA. Research published in this series may include views on policy, but the institute itself takes no institutional policy positions.

The Institute for the Study of Labor (IZA) in Bonn is a local and virtual international research center and a place of communication between science, politics and business. IZA is an independent nonprofit organization supported by Deutsche Post Foundation. The center is associated with the University of Bonn and offers a stimulating research environment through its international network, workshops and conferences, data service, project support, research visits and doctoral program. IZA engages in (i) original and internationally competitive research in all fields of labor economics, (ii) development of policy concepts, and (iii) dissemination of research results and concepts to the interested public.
\end{abstract}

IZA Discussion Papers often represent preliminary work and are circulated to encourage discussion. Citation of such a paper should account for its provisional character. A revised version may be available directly from the author. 
IZA Discussion Paper No. 5618

April 2011

\section{ABSTRACT \\ Incentives and Cooperation in Firms: Field Evidence}

We empirically investigate the impact of incentive scheme structure on the degree of cooperation in firms using a unique and representative data set. Combining employee survey data with detailed firm level information on the relative importance of individual, team, and company performance for compensation, we find a significant positive relation between the intensity of team incentives and several survey measures of cooperation. Moreover, higher powered team incentives are associated with lower degrees of absenteeism while this is not the case for individual incentives.

JEL Classification: D23, J33, M52, M54

Keywords: incentives, cooperation, teams, helping effort

Corresponding author:

Dirk Sliwka

University of Cologne

Herbert-Lewin-Strasse 2

50931 Cologne

Germany

E-mail: dirk.sliwka@uni-koeln.de 


\section{Introduction}

Economic theory has often stressed that compensation based on team performance is accompanied by the danger of free-riding and consequently inefficient employee efforts. This problem has been discussed comprehensively in the theoretical and empirical literature. ${ }^{1}$ However, several arguments in favor of team-based compensation were brought forward. A key argument is that under team-based incentive schemes employees should be more inclined to support teammates fulfilling their tasks which in turn is beneficial for the employer. Itoh (1991) and Itoh (1992), for instance, analyze formal models showing that it can be worthwhile to base agents' rewards not only on individual but also on co-worker performance when there is scope for mutual helping efforts. ${ }^{2}$ On the other hand, incentive schemes purely based on individual performance may reduce the willingness to help each other when helping takes away time and resources from working on individual tasks (see for instance Lazear (1989), Drago and Garvey (1998), Encinosa et al. (2007), Burks et al. (2009)).

In this paper we investigate the connection between the structure of compensation schemes and the inclination to help co-workers empirically. We use a unique and representative employer-employee matched survey which was conducted by the Great-Place-to-Work Institute, a company specialized in conducting employee surveys, on behalf of the German Federal Ministry of Labor and Social Affairs in 2006. The data set is a sample of 305 German firms containing company-level information about workers' and managers $^{6}$ performance-related payment schemes. In addition, in each firm an employee-survey has been conducted containing detailed information about

\footnotetext{
${ }^{1}$ See for instance Holmström (1982), Alchian and Demsetz (1972) and Newhouse (1973), or Prendergast (1999) for a survey.

${ }^{2}$ See also Holmström and Milgrom (1991), Drago and Garvey (1998) and Dur and Sol (2010). Within a dynamic framework Auriol et al. (2002) point out that team contracts also reduce potential negative effects of career concerns by weakening incentives to reduce colleagues' performance.
} 
work satisfaction of approximately 36,000 workers.

We find that the intensity of team-based compensation schemes is significantly positively related to several measures of cooperation. However, neither incentives based on individual nor on firm performance affect cooperation among employees. The positive link between team-based incentives and cooperation is substantial: For example, a 10 percentage point increase in the share of team-based compensation (as a percentage of total compensation) is associated with an $11 \%$ increase in the number of employees who agree to the statement that in the firm "you can count on people to cooperate". This relationship depends on workforce size and is stronger in smaller companies.

The data set also provides a direct survey question on the employees' general preference for helping others which allows us to disentangle selection from incentive effects: The effect remains basically unchanged when we control for helping preferences. Moreover, while there are strong inter-industry differences in the preference for helping we find no differences between firms with and without team compensation schemes. Hence, we can rule out that the results are driven by the self-selection of more cooperative employees into organizations that use team-based incentives.

In addition we investigate the connection between the structure of incentive schemes and absenteeism. In line with the previous observations we also find evidence for less absenteeism in the presence of team incentive plans.

While there is now some consistent field evidence showing positive effects of team incentive plans on performance (e.g. Jones and Kato (1995), Knez and Simester (2001), Hamilton et al. (2003), Bandiera et al. (2009) Jones et al. (2010)), there are, to the best of our knowledge, only a very limited number of studies focusing on the link between team incentives and helping on the job. Drago and Garvey (1998) detect no relationship between helping efforts and the existence of piece rates or profit sharing using data from a survey of nonsupervisory employees at 23 Australian workplaces where help- 
ing effort is measured using responses to a survey question "To what extent do your fellow employees refuse to let others use their equipment, tools, or machinery?". Heywood et al. (2005) analyze the relationship between profit sharing and cooperation with the 1995 wave of the German Economic Panel and find a positive association between profit sharing and the perception that employees get along well with their colleagues. While these studies use only binary information, our data set contains information about the presence and the strength of individual, team- and firm-based performance pay which allows us to distinguish between the effects of these three components which typically make up incentive plans.

Our second result that team incentives are associated with lower absenteeism rates is in line with recent findings by Knez and Simester (2001), Bhattacherjee (2005) and Roman (2009). A possible explanation is given by Kandel and Lazear (1992) who identify team incentives as a determinant for peer pressure. While evidence from field studies (Ichino and Maggi (2000), Sacerdote (2001), Mas and Moretti (2009), Bandiera et al. (2010)) or experiments (see for instance Falk and Ichino (2006), Mohnen et al. (2008)) highlight the importance of peer effects in general, field evidence on the connection between the structure of incentive schemes and peer effects is still rather scarce.

The remainder of the paper is organized as follows: In the next section we present the two data sets, the matching procedure and our hypotheses. Section 3 presents our main results. To meet endogeneity issues often raised in cross-sectional research designs, this section also includes several sub sample analyses and control specifications. In section 3.3 we present our findings concerning absenteeism and team incentives, before concluding in section 4 . 


\section{Data and Hypotheses}

Our data source is a 2006 employer-employee matched survey conducted by the Great-Place-to-Work Institute and the German Federal Ministry of Labor and Social Affairs. The data set is a representative sample of 305 German firms employing a minimum of 20 workers. For each firm the management provided company-level information on organizational facts, corporate values as well as on various HR practices such as trainings, benefits and compensation. Most of this information is provided separately for managers and workers in each firm. ${ }^{3}$

In addition to this firm-level information, a representative employeesurvey was conducted at each sampled firm yielding over 36,000 observations in total. Among others the employee survey includes 58 standardized items to be answered on a 5-point Likert scale which are designed to measure the level of trust, pride, and cooperation within firms. More precisely the items focus on the relationship between employees and management, the work environment, and the relationship between employees. In our analysis we focus on the last aspect, i.e. the perceived level of cooperation among colleagues.

Due to the random sampling process the 305 firms are almost evenly spread across the different industries in Germany. The majority of the sampled firms are small or medium sized. While the average number of employees amounts to 430 , the median is at 157 . However, roughly $10 \%$ of the firms employ more than 1,000 workers including the largest firm in the sample with 14,000 workers.

Previous studies (e.g. Drago and Garvey (1998), Heywood et al. (2005)) mainly relied on binary information about whether workers participate in firm profits. Our data set allows a more in depths analysis on how much employees benefit from economic outcomes and which pay components drive the effects. Each firm stated whether wages for managers and workers in the

\footnotetext{
${ }^{3}$ More specifically, answers were provided for employees in supervisory function and for the largest group of non-managerial employees, i.e. the core occupational group.
} 
corresponding firm include a performance-related pay component. For both, managers and workers, we know the share of the average wage (in \%) which is determined by performance-related pay (henceforth PRP). Furthermore, firms reported how much (in \%) of total PRP is determined by either individual, team, or firm performance. Multiplying these numbers, we derive the fractions (in \%) of the total wage that are based on the three different types of PRP.

Figure 1 gives a descriptive overview of PRP usage across industries showing the share of firms using PRP. While the majority of sampled firms use variable pay components for managers, the use of worker PRP varies from only $6 \%$ of all organizations in the Public Sector to $71 \%$ in Financial Services. In total 109 out of $294^{4}$ firms use PRP for their core occupational group. Figure 2 shows the composition of workers' incentives across industries. Though firm- and team-based variable compensation is quite common, individual incentive schemes have the prominent role. Roughly $55 \%$ of variable wage components are based on individual performance. Table 1 reports the average strength of incentives for the subset of firms who use at least one type of worker PRP. The mean magnitude of worker's incentive pay amounts to roughly $12 \%$ of the fixed wage. While workers' incentive pay is mainly based on individual performance, the largest fraction of managers' incentives is determined by the economic success of the company as a whole. For both groups, team incentives are relatively low. In firms using worker PRP, team incentives only account for $18 \%$ of total incentives and thus for only $2.2 \%$ of the total average wage.

Complementing the firm level information provided by management, we exploit the employee surveys conducted in each firm to measure the degree of cooperation among the workforce. ${ }^{5}$ Table 2 shows 4 items of the employee survey which reflect workers' perception of teamwork and team atmosphere

\footnotetext{
${ }^{4} 11$ out of the 305 sampled firms did not provide information on PRP.

${ }^{5}$ In firms with less than 500 employees all employees were asked to participate. In larger firms a representative 500-employee sample was drawn.
} 


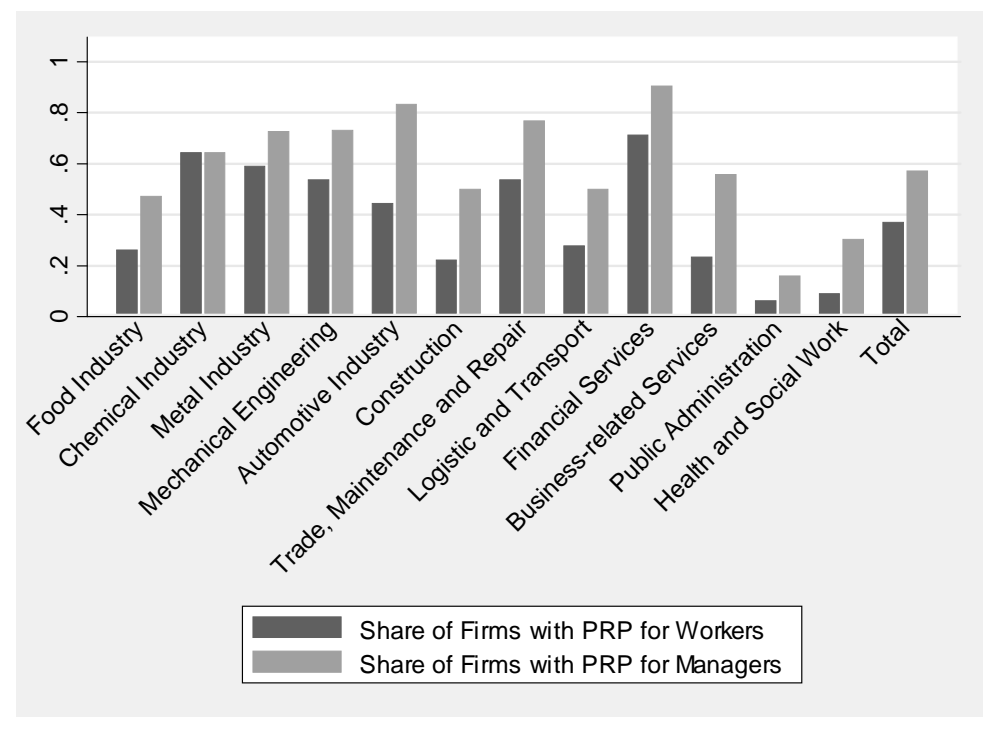

Figure 1: Utilization of performance-related pay across German industries

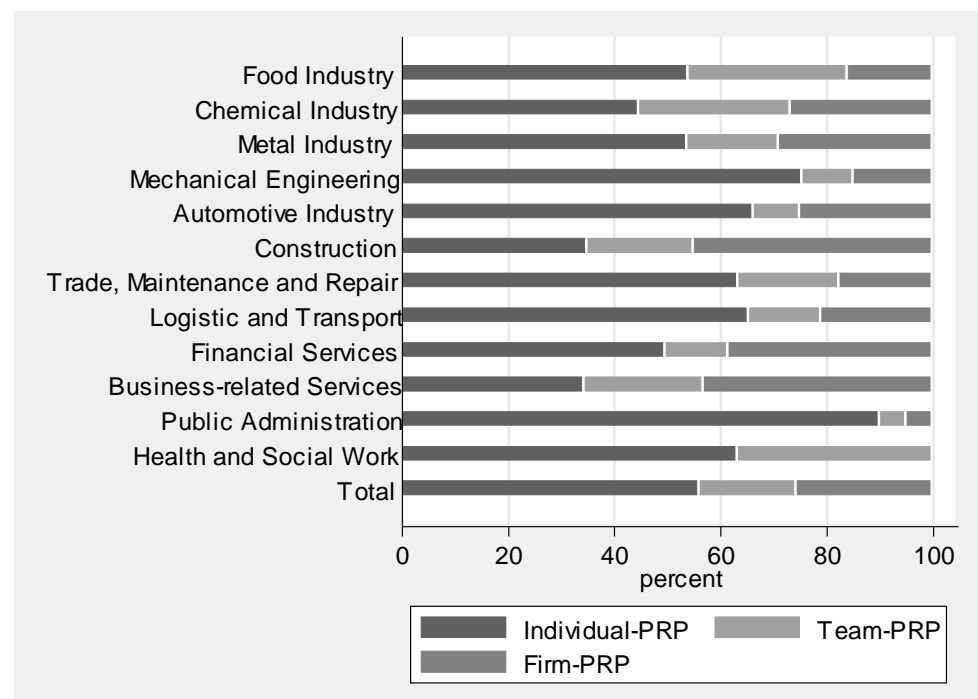

Figure 2: Structure of performance-related pay across German industries 


\begin{tabular}{llcc}
\hline \hline Variable & Description & Workers & Managers \\
\hline Individual PRP & \% of Individual PRP on Average Wages & $7.5 \%$ & $4.8 \%$ \\
Team PRP & \% of Team PRP on Average Wages & $2.2 \%$ & $4.4 \%$ \\
Firm PRP & \% of Firm PRP on Average Wages & $2.6 \%$ & $8.4 \%$ \\
\hline Total PRP & Total Percentage of PRP on Average Wages & $12.4 \%$ & $17.6 \%$ \\
\hline \hline
\end{tabular}

Table 1: Utilization of performance-related pay in the sample

within a firm. All items use the same 5-point Likert scale ranging from 1 "almost always untrue" to 5 "almost always true" and refer to the company as a whole. The table displays simple descriptive statistics of responses given by full-time workers in all sampled firms. ${ }^{6}$ The top-box column shows the percentage of workers who affirm a statement by choosing 4 or 5 on the 5 point scale. Overall $54.6 \%$ of the responders affirm the statement "You can count on people to cooperate". The share of workers in a firm agreeing to an item serves as a dependent variable and is coded between 0 and 100 .

\begin{tabular}{llcc}
\hline \hline Variable & Description & Top-Box & Sd \\
\hline (1) Cooperate & "You can count on people to cooperate" & $54.6 \%$ & 17.6 \\
(2) Care & "People care about each other" & $52.5 \%$ & 18.1 \\
(3) Team Spirit & "There is a "family" or "team" feeling here" & $45.9 \%$ & 19.2 \\
(4) Backstab & "People avoid politicking and backstabbing" & $47.6 \%$ & 18.1 \\
\hline \hline
\end{tabular}

Table 2: Survey items approximating cooperation

Detailed firm level information on PRP and suitable measures for team work in the firm allow for testing the relationship between incentives and the level of cooperation. We expect cooperation in firms to be positively affected by team incentives. The relation between individual incentives and cooperation depends is less clear cut. If supplying helping effort raises the costs for supplying 'private' effort, individual incentives reduce the inclination to

\footnotetext{
${ }^{6}$ Full-time employees with non-supervisory function are most likely to correspond to "the largest share of employees in the firm" addressed in the management survey questions. In the analysis of worker pay schemes on cooperation we therefore restrict our analysis to the answers given by this group.
} 
help co-workers. If costs for helping effort are, however, independent of the costs of 'private' effort supply, individual incentives do not affect helping on the job (see Itoh (1991)). Incentives based on firm performance only gradually differ from team incentives since a firm can been seen as a large team. However, the marginal effect on firm performance should be much smaller than the effect on team performance measures. Secondly, peer pressure is less likely to be sustainable as mutual monitoring becomes impracticable in larger teams. Hence, we expect to find a weaker relationship between firm level incentives and cooperation.

Several other firm specific characteristics might also contribute to the level of perceived cooperation. As laid out, the level of cooperation within a firm should be influenced by the number of workers composing a team unit. We use the number of hierarchical levels to control for potential differences in team unit size across firms. For a given workforce size more hierarchical levels should positively affect cooperation among workers due to a smaller average team size. However, more hierarchical levels might also entail stronger promotion based incentives which in turn generate incentives to refrain from helping or even to sabotage colleagues (see Lazear (1989) and Drago and Garvey (1998)).

Moreover, the effect of team performance pay on cooperation might be mitigated by workforce size. Large firms tend to offer a greater variety of workplaces and development possibilities. Employees can avoid peer pressure by changing team, division, or location. Workers in small firms have fewer within-firm exit options and are exposed to potential peer pressure to a higher degree. Therefore, team-based compensation in small firms may lead to higher degrees of cooperation. In small firms employees are also more likely to interact in the future because the number of potential co-workers is limited. Hence, behavioral responses to team incentives do not only affect present but also future interaction with colleagues and should therefore foster cooperation. Che and Yoo (2001), for instance, show that under team 
incentives a higher frequency of future interactions increases productivity in a repeated game.

\section{Results}

\subsection{Team Incentives and Cooperation}

To study the relationship between incentives and the level of cooperation we match the firm-level information obtained in the management survey to the percentage of workers' affirmative answers to the survey items on cooperation. We then estimate the relation between incentive scheme structure and the percentage of workers agreeing to these cooperation items with OLS regressions. ${ }^{7}$ We control for firm characteristics such as firm size, industry and the presence of a works council. As noted above, we include the number of hierarchical levels to approximate team unit size when the firm size is controlled for.

Table 3 presents our main results. ${ }^{8}$ Team PRP is indeed significantly and positively related to all cooperation items. In economic terms, a $10 \%$ point higher team PRP is associated with 6 percentage point increase in the fraction of affirmative answers to the item "You can count on people to cooperate". The predicted fraction of employees agreeing to that statement at the mean of all other explanatory variables is equal to $54.3 \%$ when there is no team PRP and this fraction increases by about $11 \%$ to $60.3 \%$ of all employees when team PRP is $10 \%$ instead. The effect is of similar magnitude for all four items.

However, we do not find any relationship between our measures of cooperation and the strength of firm incentives. Also, higher individual incentives do not seem to be harmful for the perceived degree of cooperation. This indi-

\footnotetext{
${ }^{7}$ Note that that there are nearly no observations of the dependent variables at the boundary of the $[0,100]$ interval. Hence, tobit regressions lead to nearly identical results.

${ }^{8}$ Table A1 gives descriptive statistics of all explanatory variables.
} 
cates that there are no or rather low substitution effects between individual and helping efforts. ${ }^{9}$ Furthermore, it is interesting to note that employees state a higher rate of cooperation if their firm organizes work in smaller team units as suggested by the positive coefficient of Hierarchical Levels while controlling for firm size.

All Firms

\begin{tabular}{lcccc}
\hline \hline Dependent Variable & Cooperate & Care & Team Spirit & Backstab \\
& $(1)$ & $(2)$ & $(3)$ & $(4)$ \\
\hline Individual PRP & 0.023 & 0.050 & 0.147 & 0.172 \\
& $(0.134)$ & $(0.118)$ & $(0.153)$ & $(0.135)$ \\
Team PRP & $0.599^{* * *}$ & $0.487^{* * *}$ & $0.620^{* * *}$ & $0.575^{* * *}$ \\
& $(0.227)$ & $(0.182)$ & $(0.167)$ & $(0.195)$ \\
Firm PRP & 0.056 & 0.170 & 0.380 & -0.126 \\
& $(0.344)$ & $(0.420)$ & $(0.527)$ & $(0.572)$ \\
Hierarchical Levels & $3.268^{* * *}$ & $3.529^{* * *}$ & $1.790^{* *}$ & $1.824^{*}$ \\
& $(0.827)$ & $(0.962)$ & $(0.877)$ & $(1.089)$ \\
Works Council & $-4.734^{* *}$ & $-4.524^{*}$ & $-5.007^{*}$ & $-9.103^{* * *}$ \\
& $(2.329)$ & $(2.561)$ & $(2.808)$ & $(2.459)$ \\
Constant & $55.355^{* * *}$ & $51.677^{* * *}$ & $48.863^{* * *}$ & $53.493^{* * *}$ \\
& $(5.531)$ & $(6.024)$ & $(5.752)$ & $(6.193)$ \\
\hline Observations & 281 & 281 & 281 & 281 \\
$R^{2}$ & 0.216 & 0.190 & 0.152 & 0.180 \\
\hline \hline$* * * \mathrm{p}<0.01, * * \mathrm{p}<0.05, * \mathrm{p}<0.1$, & &
\end{tabular}

OLS regression: further controls: 2 firm size dummies and 11 industry dummies

Reference category: 0-99 employee firm in the food industry

Table 3: Performance-related pay and cooperation among workers

According to our hypothesis we should expect a stronger impact of team incentives in smaller firms. Table 4 captures the interaction between incentive pay and firm size. Note that for 3 of 4 items, the effect of team

\footnotetext{
${ }^{9}$ In the notation of Itoh's (1991) model, the employees seem to rather have "task specific" disutility of effort such that their individual cost functions are rather additively separable in costs for individual efforts and costs for helping efforts with vanishing cross derivatives.
} 
compensation negatively interacts with workforce size. The relation between team incentives and cooperation is thus particularly strong in small firms and tends to diminish with workforce size. In our linear interaction the relationship between team incentives and cooperation vanishes at a workforce size of approximately 400 .

As a further robustness check we consider two more homogenous subsamples of firms. First, we restrict the analysis to firms which use at least one form of performance based pay. In the next step we consider only firms which use team incentives for their employees. The left panel of table 5 shows results for firms which use at least one type of PRP. We again find a positive and significant relationship between team incentives and cooperation, comparable in magnitude and statistical significance with the proceeding analysis. The right panel displays a similar picture for the subsample of firms using team PRP. Even in this drastically reduced sample our main result remains robust across all four items. ${ }^{10}$

\footnotetext{
${ }^{10}$ Due to the reduced sample of 40 firms, we do not include industry dummies in these specifications. In the preceeding analysis industries showed little statistically significance. Including industry dummies here yields a 20 regressor- 40 observation regression with no significant estimates.
} 
All Firms

\begin{tabular}{|c|c|c|c|c|}
\hline Dependent Variable & $\begin{array}{c}\text { Cooperate } \\
(1)\end{array}$ & $\begin{array}{c}\text { Care } \\
(2)\end{array}$ & $\begin{array}{c}\text { Team Spirit } \\
(3)\end{array}$ & $\begin{array}{c}\text { Backstab } \\
(4)\end{array}$ \\
\hline \multirow[t]{2}{*}{ Individual PRP } & 0.032 & 0.058 & 0.106 & 0.211 \\
\hline & $(0.177)$ & $(0.153)$ & $(0.200)$ & $(0.181)$ \\
\hline \multirow[t]{2}{*}{ Team PRP } & $0.679^{* *}$ & $0.667^{* * *}$ & $0.787^{* * *}$ & $0.774^{* * *}$ \\
\hline & $(0.289)$ & $(0.220)$ & $(0.205)$ & $(0.206)$ \\
\hline \multirow[t]{2}{*}{ Firm PRP } & 0.216 & 0.273 & 0.354 & -0.218 \\
\hline & $(0.458)$ & $(0.553)$ & $(0.686)$ & $(0.757)$ \\
\hline \multirow[t]{2}{*}{ Workers/100 } & 0.001 & $0.002^{*}$ & 0.001 & $0.004^{* * *}$ \\
\hline & $(0.002)$ & $(0.001)$ & $(0.002)$ & $(0.001)$ \\
\hline \multirow[t]{2}{*}{ Individual $\mathrm{PRP} \times$ Workers $/ 100$} & 0.018 & 0.023 & 0.022 & 0.001 \\
\hline & $(0.021)$ & $(0.019)$ & $(0.023)$ & $(0.022)$ \\
\hline \multirow[t]{2}{*}{ Team PRP $\times$ Workers $/ 100$} & -0.068 & $-0.176^{* *}$ & $-0.190^{* *}$ & $-0.196^{* *}$ \\
\hline & $(0.105)$ & $(0.081)$ & $(0.095)$ & $(0.083)$ \\
\hline \multirow[t]{2}{*}{ Firm PRP $\times$ Workers $/ 100$} & -0.041 & -0.010 & 0.015 & 0.072 \\
\hline & $(0.066)$ & $(0.065)$ & $(0.076)$ & $(0.085)$ \\
\hline \multirow[t]{2}{*}{ Hierarchical Levels } & $3.243^{* * *}$ & $3.475^{* * *}$ & $1.739^{*}$ & 1.759 \\
\hline & $(0.835)$ & $(0.956)$ & $(0.885)$ & $(1.110)$ \\
\hline \multirow[t]{2}{*}{ Works Council } & $-4.894^{* *}$ & $-4.780^{*}$ & $-5.139 *$ & $-9.403^{* * *}$ \\
\hline & $(2.364)$ & $(2.593)$ & $(2.842)$ & $(2.492)$ \\
\hline \multirow[t]{2}{*}{ Constant } & $55.462^{* * *}$ & $52.033^{* * *}$ & $49.297^{* * *}$ & $53.969^{* * *}$ \\
\hline & $(5.619)$ & $(6.090)$ & $(5.826)$ & $(6.304)$ \\
\hline Observations & 281 & 281 & 281 & 281 \\
\hline$R^{2}$ & 0.219 & 0.198 & 0.155 & 0.192 \\
\hline
\end{tabular}

OLS regression: further controls: 11 industry dummies

Reference category: 0-99 employee firm in the food industry

Table 4: Performance-related pay, cooperation among workers and firmsize 


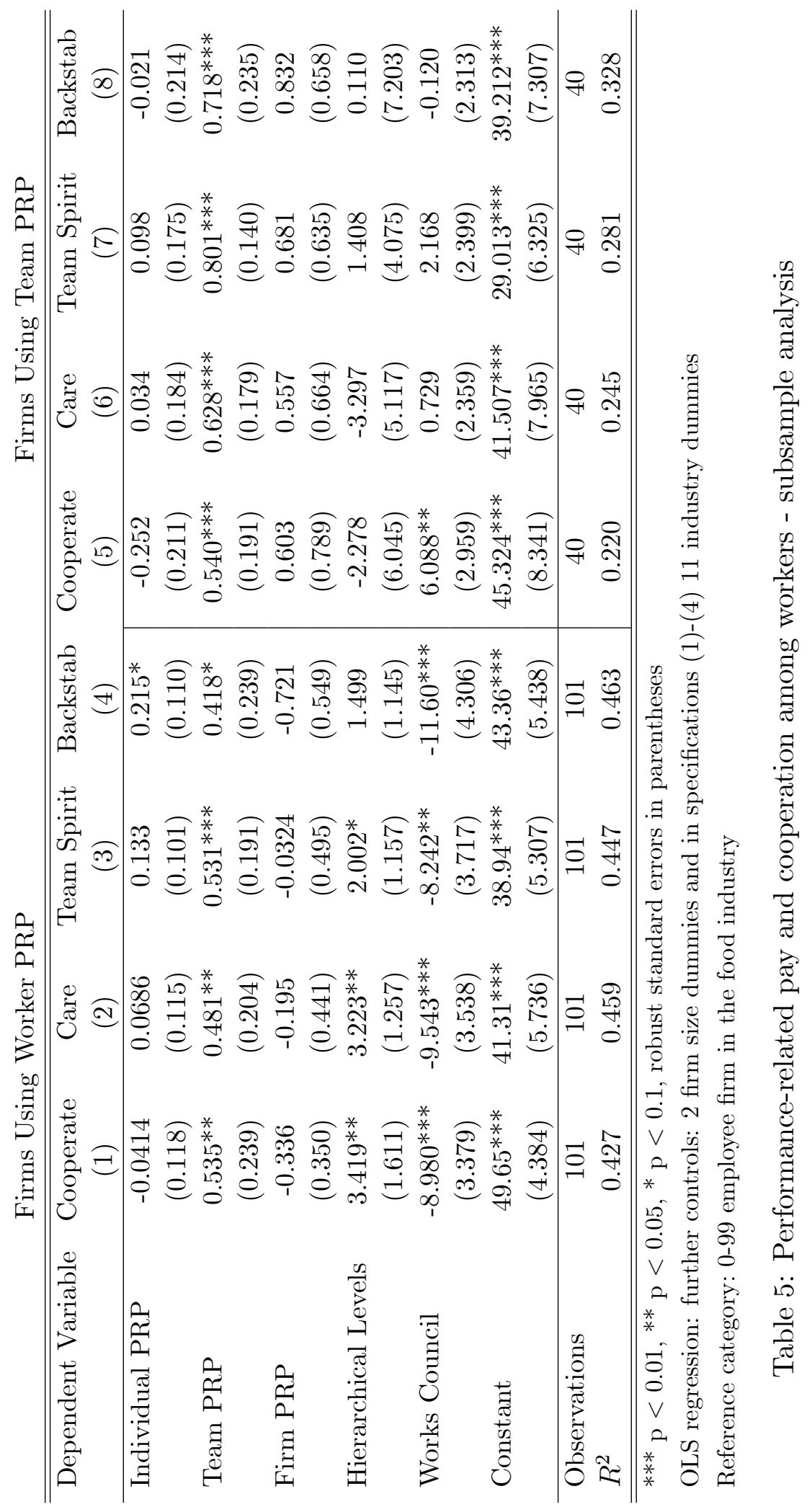


As the management survey contains detailed information on other management practices we are able to control for further firm characteristics that are potentially confounding factors: The fraction of part-time employees, for instance, may affect the intensity of daily interaction of the workforce. Information about the wage level captures the company's wage policy and the attractiveness of a workplace. Whether a firm is currently downsizing or upsizing may have effects on the level of cooperation and may also affect the structure of compensation. Trainings could foster social interaction among the workforce and thereby affect cooperation. The presence of systematic female career support reflects the company's antidiscriminatory efforts and attempts to create a fair working environment. Furthermore, the general working climate, captured by the share of workers who are satisfied with their current job, may not only influence cooperative behavior but may also be influenced by the company's wage scheme. Table A2 shows estimates for column 1 of our basic specification from table 3 and the additional controls discussed above. ${ }^{11}$ The effect of team PRP remains statistically and economically stable over all specifications, indicating a robust relationship between team PRP and cooperation among the workforce. ${ }^{12}$

\subsection{Incentives or Self-Selection?}

It is important to understand the key mechanism by which team incentives affect cooperation in more detail. Indeed, a given set of employees should have stronger incentives to cooperate if team performance is rewarded. But in addition, self-selection could also play a role as workers with preferences for cooperation may self-select into firms with team incentives. Then cooperation should increase simply due to the different composition of the workforce. Lazear (2000), for instance, showed in his seminal study on the effect of

\footnotetext{
${ }^{11}$ Regressions for all other items show almost identical patterns.

${ }^{12}$ The substantially reduced number of observations in the last column results from missing values in firms' training-, or gender career programs.
} 
piece rates on productivity that about half of the productivity effect was due to self-selection. Moreover, recent laboratory studies (e.g. Cadsby et al. (2007), Dohmen and Falk (2009), Eriksson and Villeval (2008)) suggest that payment scheme design causes sorting effects not only with respect to agents ${ }^{6}$ abilities but also to their social preferences.

To investigate the self-selection argument in our data we explore another subsection of the employee survey in which employees were asked which aspects of a job are important to them in general. Besides job security, high income or promotion opportunities, workers were also asked: "How important is it for you to have a profession in which you can help others?" which should capture an individual's general willingness to help others. If selfselection with respect to the specific structure of performance pay plays a role, we should expect the fraction of workers with a preference for helping to be higher in firms that tie rewards to team or firm performance. Including the fraction of workers with a preference for helping as an additional control in our baseline specification should then also reduce the coefficient of team PRP.

In the models reported in table 6 we first regress the share of workers in a firm stating that a job in which one can help others is important or very important to them on the structure of incentive pay and our set of standard firm controls. Again we run the regressions for the entire sample but also for the Using-PRP and Using-Team-PRP subsamples. In none of the specifications neither individual, team nor firm PRP significantly explain the share of employees to whom helping is important. ${ }^{13}$

We also included this measure of the employees' general preference for helping in our basic OLS estimation to control for the share of cooperative workers in the firm. The results are displayed in table 7 and show that the coefficients of our variables of interest remain almost unchanged. Hence, we

\footnotetext{
${ }^{13}$ Note that we do find, for instance, that the share of workers stating that a high income is important to them increases in the strength of individual incentives.
} 


\begin{tabular}{|c|c|c|c|}
\hline \multirow[t]{2}{*}{ Dependent Variable } & \multicolumn{3}{|c|}{ Preference for Helping } \\
\hline & $\begin{array}{l}\text { All Firms } \\
\quad(1)\end{array}$ & $\begin{array}{c}\text { Using PRP } \\
\quad(2)\end{array}$ & $\begin{array}{c}\text { Using Team PRP } \\
(3)\end{array}$ \\
\hline \multirow[t]{2}{*}{ Individual PRP } & 0.0218 & -0.0524 & 0.261 \\
\hline & $(0.114)$ & $(0.149)$ & $(0.407)$ \\
\hline \multirow[t]{2}{*}{ Team PRP } & -0.324 & -0.184 & -0.483 \\
\hline & $(0.284)$ & $(0.280)$ & $(0.304)$ \\
\hline \multirow[t]{2}{*}{ Firm PRP } & -0.177 & -0.111 & -0.546 \\
\hline & $(0.327)$ & $(0.450)$ & $(0.955)$ \\
\hline \multirow[t]{2}{*}{ Hierarchical Levels } & 0.0146 & -0.813 & -2.756 \\
\hline & $(0.519)$ & $(1.015)$ & $(5.109)$ \\
\hline \multirow[t]{2}{*}{ Works Council } & $-4.692^{* * *}$ & $-7.636^{* *}$ & $-18.31^{* *}$ \\
\hline & $(1.698)$ & $(3.706)$ & $(6.991)$ \\
\hline \multirow[t]{2}{*}{ Constant } & $88.28^{* * *}$ & $82.15^{* * *}$ & $93.70^{* * *}$ \\
\hline & $(2.549)$ & $(4.849)$ & $(11.97)$ \\
\hline Observations & 281 & 101 & 40 \\
\hline$R^{2}$ & 0.339 & 0.345 & 0.633 \\
\hline \multicolumn{4}{|c|}{${ }^{* * *} \mathrm{p}<0.01,{ }^{* *} \mathrm{p}<0.05,{ }^{*} \mathrm{p}<0.1$, robust standard errors in parenthese } \\
\hline \multirow{2}{*}{\multicolumn{4}{|c|}{$\begin{array}{l}\text { OLS regression: further controls: } 2 \text { firm size dummies } \\
\text { and } 11 \text { industry dummies }\end{array}$}} \\
\hline & & & \\
\hline \multicolumn{4}{|c|}{ Reference category: 0-99 employee firm in the food industry } \\
\hline
\end{tabular}


conclude that self-selection seems to be no key driver for the positive relation between team incentive schemes and cooperation in our data.

\begin{tabular}{lcccc}
\multicolumn{5}{c}{ All Firms } \\
\hline \hline Dependent Variable & Cooperate & Care & Team Spirit & Backstab \\
& $(1)$ & $(2)$ & $(3)$ & $(4)$ \\
\hline Individual PRP & 0.022 & 0.052 & 0.146 & 0.174 \\
& $(0.138)$ & $(0.115)$ & $(0.154)$ & $(0.133)$ \\
Team PRP & $0.622^{* * *}$ & $0.464^{* *}$ & $0.631^{* * *}$ & $0.555^{* * *}$ \\
& $(0.222)$ & $(0.188)$ & $(0.172)$ & $(0.198)$ \\
Firm PRP & 0.069 & 0.157 & 0.386 & -0.137 \\
& $(0.336)$ & $(0.432)$ & $(0.521)$ & $(0.579)$ \\
Hierarchical Levels & $3.267^{* * *}$ & $3.530^{* * *}$ & $1.790^{* *}$ & $1.825^{*}$ \\
& $(0.823)$ & $(0.959)$ & $(0.878)$ & $(1.096)$ \\
Works Council & $-4.408^{*}$ & $-4.853^{*}$ & $-4.853^{*}$ & $-9.394^{* * *}$ \\
& $(2.331)$ & $(2.593)$ & $(2.818)$ & $(2.442)$ \\
Preference for Helping & 0.069 & -0.070 & 0.033 & -0.062 \\
& $(0.111)$ & $(0.092)$ & $(0.109)$ & $(0.101)$ \\
Constant & $49.226^{* * *}$ & $57.860^{* * *}$ & $45.955^{* * *}$ & $58.971^{* * *}$ \\
& $(10.057)$ & $(9.088)$ & $(10.157)$ & $(9.928)$ \\
\hline Observations & 281 & 281 & 281 & 281 \\
$R^{2}$ & 0.217 & 0.192 & 0.152 & 0.182 \\
\hline \hline$* * * \mathrm{p}<0.01, * * \mathrm{p}<0.05, * \mathrm{p}<0.1$, robust standard errors in parentheses \\
OLS regression: further controls: 2 firm size dummies and 11 industry dummies \\
Reference category: 0-99 employee firm in the food industry &
\end{tabular}

Table 7: Performance-related pay, self selection and cooperation among workers

Interestingly, the distribution of cooperative preferences is quite heterogeneous across industries as displayed in figure A1 where we graph the coefficients of the industry dummies included in table 6. Maybe not surprisingly, the share of cooperative workers is largest in health and social assistance and lowest in financial and business-related services. The fact that our helping preference measure delivers plausible results for workers sorting into different industries makes us confident about our conclusion that incentive schemes 
do not lead to self-selection according to these preferences.

\subsection{Team Incentives and Absenteeism}

Having investigated the relationship between team incentives and perceived cooperation, we further test whether this positive relation is also reflected in more objective performance measures. A key figure that most management representatives (259 out of 305) were able to provide is the workers' average number of missed work days. In our sample a worker missed on average 9 days of work.

Absenteeism is likely to decrease with rising individual incentives. On the other hand, absenteeism is also predicted to decrease with higher team incentives. Recent studies have indicated that team incentives and increased peer pressure can effectively prevent workers from staying at home (Knez and Simester (2001), Bhattacherjee (2005) and Roman (2009)). Alternatively, if team incentives strengthen team spirit and cooperation as suggested by our study, this mechanism might additionally reduce absenteeism. In a sense, a well functioning team may prevent workers from letting their colleagues down. To further test the economic importance of team incentives, we regress yearly absenteeism days on the incentive structure observed in each firm.

Table 8 shows that higher team incentives are indeed linked to fewer absent days. In our first specification a $10 \%$ point increase in team PRP is associated with 1.4 fewer absent days per worker and year. Controlling for job satisfaction and average workforce age in specification 2, a $10 \%$ point higher team PRP comes along with one absence day less. Interestingly, individual $\mathrm{PRP}$ is far from statistical significance in both specifications. On the right side of table 8, we again restrict the analysis to firms who use PRP for their workers. Even in this substantially smaller sample, the main result that higher team incentives are associated with less absenteeism remains significant. 


\begin{tabular}{|c|c|c|c|c|}
\hline \multirow[t]{3}{*}{ Dependent Variable } & \multicolumn{4}{|c|}{ Average Absent Days } \\
\hline & \multicolumn{2}{|c|}{ All Firms } & \multicolumn{2}{|c|}{ Firms Using PRP } \\
\hline & (1) & $(2)$ & $(3)$ & (4) \\
\hline \multirow[t]{2}{*}{ Individual PRP } & 0.023 & 0.029 & -0.044 & -0.046 \\
\hline & $(0.044)$ & $(0.045)$ & $(0.067)$ & $(0.068)$ \\
\hline \multirow[t]{2}{*}{ Team PRP } & $-0.132^{* *}$ & $-0.097^{*}$ & $-0.228^{* *}$ & $-0.201^{*}$ \\
\hline & $(0.059)$ & $(0.059)$ & $(0.107)$ & $(0.113)$ \\
\hline \multirow[t]{2}{*}{ Firm PRP } & 0.010 & -0.017 & -0.174 & -0.197 \\
\hline & $(0.097)$ & $(0.099)$ & $(0.165)$ & $(0.176)$ \\
\hline \multirow[t]{2}{*}{ Works Council } & $2.738^{* * *}$ & $2.117^{* * *}$ & $2.716^{*}$ & 2.325 \\
\hline & $(0.746)$ & $(0.726)$ & $(1.386)$ & $(1.513)$ \\
\hline \multirow[t]{2}{*}{ Job Satisfaction } & & $-6.402^{*}$ & & 0.552 \\
\hline & & $(3.330)$ & & $(5.987)$ \\
\hline \multirow[t]{2}{*}{ Workforce Age } & & $0.217^{* * *}$ & & 0.134 \\
\hline & & $(0.079)$ & & $(0.162)$ \\
\hline \multirow[t]{2}{*}{ Constant } & $6.488^{* * *}$ & 3.350 & $8.690^{* * *}$ & 2.892 \\
\hline & $(0.737)$ & $(4.080)$ & $(1.420)$ & $(8.341)$ \\
\hline \multirow{2}{*}{$\begin{array}{l}\text { Observations } \\
R^{2}\end{array}$} & 248 & 248 & 92 & 92 \\
\hline & 0.258 & 0.303 & 0.346 & 0.351 \\
\hline \multicolumn{5}{|c|}{${ }^{* * *} \mathrm{p}<0.01,{ }^{* *} \mathrm{p}<0.05,{ }^{*} \mathrm{p}<0.1$, robust standard errors in parentheses } \\
\hline \multirow{2}{*}{\multicolumn{5}{|c|}{$\begin{array}{l}\text { OLS regression: Further controls: } 2 \text { firm size dummies and } \\
11 \text { industry dummies }\end{array}$}} \\
\hline & & & & \\
\hline \multicolumn{5}{|l|}{ Reference category: 0- } \\
\hline
\end{tabular}

Table 8: Performance-related pay and absenteeism 


\section{Conclusion}

The aim of this study was to identify the relationship between incentive schemes and the level of cooperation among workers. We could make use of a large representative employer-employee survey spanning a representative sample of firms from all industries which contains much more detailed information on the structure of incentive schemes as compared to data sets that have previously been used. Investigating this data set, we detected a positive relationship between the intensity of average team incentives in a firm and perceived helping efforts. We did not find similar effects for variable compensation based on company performance. This observation is well in line with what we expect from a standard agency model: Apparently, performance pay based on overall firm success is not sufficient to induce higher helping efforts as there is a large free rider problem which is much weaker when the performance of specific teams is measured. Moreover, our results indicate that higher individual performance pay has no negative consequences for helping efforts and that the positive effects of team incentives are not driven by self-selection. In line with these findings we also found less absenteeism in firms providing stronger team incentives but not in firms using higher levels of individual performance pay.

All in all, our results strongly support the idea that team incentive schemes are a key component in a firm's incentive strategy and substantially affect the level of cooperation in organizations.

\section{References}

Alchian, A. A. and H. Demsetz (1972). Production, information costs, and economic organization. American Economic Review 62, 777-795.

Auriol, E., G. Friebel, and P. L. (2002). Career concerns in teams. Journal of Labor Economics 20, 289-307. 
Bandiera, O., I. Barankay, and I. Rasul (2009). Team incentives: Evidence from a field experiment. Working Paper.

Bandiera, O., I. Barankay, and I. Rasul (2010). Social incentives in the workplace. Review of Economic Studies 77, 417-458.

Bhattacherjee, D. (2005). The effects of group incentives in an indian firm: Evidence from payroll data. Labour 19, 147-173.

Burks, S., J. Carpenter, and L. Goette (2009). Performance pay and worker cooperation: Evidence from an artefactual field experiment. Journal of Economic Behavior \& Organization 70, 458-469.

Cadsby, C. B., F. Song, and F. Tapon (2007). Sorting and incentive effects of pay for performance: An experimental investigation. Academy of Management Journal 50, 387-405.

Che, Y.-K. and S.-W. Yoo (2001). Optimal incentives for teams. American Economic Review 91, 525-54.

Dohmen, T. and A. Falk (2009). Performance pay and multi-dimensional sorting: Productivity, preferences and gender. American Economic Review forthcoming.

Drago, R. and G. T. Garvey (1998). Incentives for helping on the job: Theory and evidence. Journal of Labor Economics 16, 1-25.

Dur, R. and J. Sol (2010). Social interaction, co-worker altruism, and incentives. Games and Economic Behavior 69, 293-301.

Encinosa, W., M. Gaynor, and J. B. Rebitzer (2007). The sociology of groups and the economics of incentives: Theory and evidence on compensation systems. Journal of Economic Behavior \&S Organization 62, 187-214.

Eriksson, T. and M. C. Villeval (2008). Performance-pay, sorting and social motivation. Journal of Economic Behavior \& Organization 68, 412 - 421. 
Falk, A. and A. Ichino (2006). Clean evidence on peer effects. Journal of Labor Economics 24, 39-57.

Hamilton, B. H., J. A. Nickerson, and O. Owan (2003). Team incentives and worker heterogeneity: An empirical analysis of the impact of teams on productivity and participation. Journal of Political Economy 111, 465497.

Heywood, J. S., U. Jirjahn, and G. Tsertsvadze (2005). Getting along with colleagues - does profit sharing help or hurt? Kyklos 58, 557-573.

Holmström, B. (1982). Moral hazard in teams. Bell Journal of Economics 13, $324-340$.

Holmström, B. and P. Milgrom (1991). Multitask principal-agent analyses: Incentive contracts, asset ownership and job design. Journal of Law, Economics and Organization \%, 24-52.

Ichino, A. and G. Maggi (2000). Work environment and individual background: Explaining regional shirking differentials in a large italian firm. Quarterly Journal of Economics 115, 1057-1090.

Itoh, H. (1991). Incentives to help in multi-agent situations. Econometrica 3, $611-636$.

Itoh, H. (1992). Cooperation in hierachical organizations: An incentive perspective. Journal of Law, Economiocs, $\&$ Organization 8, 321-345.

Jones, D. C., P. Kalmu, and A. Kauhanen (2010). Teams, incentive pay, and productive efficiency: Evidence form a food-processing plant. Industrial Labor Relations Review 63, 606-626.

Jones, D. C. and T. Kato (1995). The productivity effects of employee stockownership plans and bonuses: Evidence from japanese panel data. American Economic Review 85, 391-414. 
Kandel, E. and E. P. Lazear (1992). Peer pressure and partnerships. Journal of Political Economy 100, 801-17.

Knez, M. and D. Simester (2001). Firm-wide incentives and mutual monitoring at continental airlines. Journal of Labor Economics 19, 743-772.

Lazear, E. P. (1989). Pay equality and industrial politics. Journal of Political Economy 97, 561-580.

Lazear, E. P. (2000). Performance pay and productivity. American Economic Review 90, 1346-62.

Mas, A. and E. Moretti (2009). Peers at work. American Economic Review 99, 112-145.

Mohnen, A., K. Pokorny, and D. Sliwka (2008). Transparency, inequity aversion, and the dynamics of peer pressure in teams: Theory and evidence. Journal of Labor Economics 26, 693-720.

Newhouse, J. (1973). The economics of group practice. Journal of Human Resources 8, 37-56.

Prendergast, C. J. (1999). The provision of incentives in firms. Journal of Economic Literature 37, 7-63.

Roman, F. J. (2009). An analysis of changes to a team-based incentive plan and its effects on productivity, product quality, and absenteeism. Accounting, Organizations and Society 34, 589-618.

Sacerdote, B. (2001). Peer effects with random assignment: Results for dartmouth roommates. Quarterly Journal of Economics 116, 681-704. 


\section{Appendix}




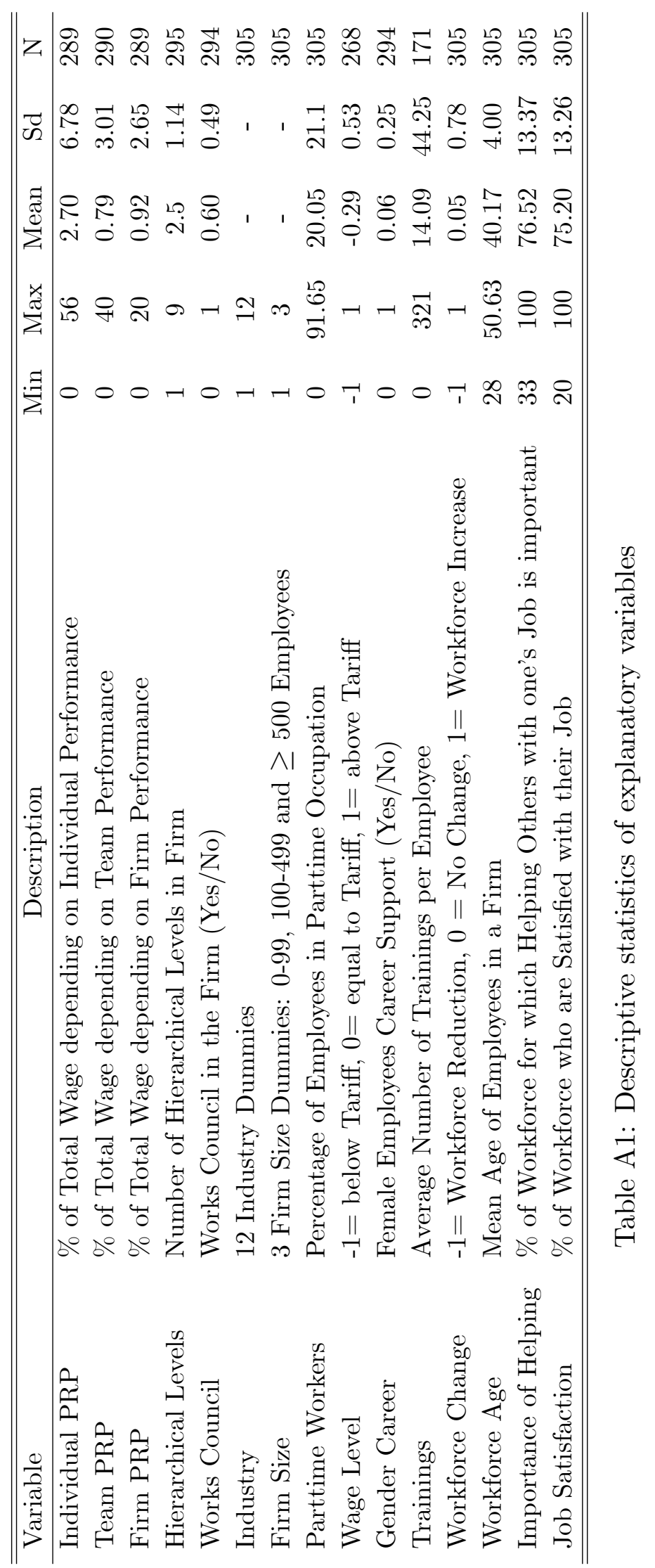




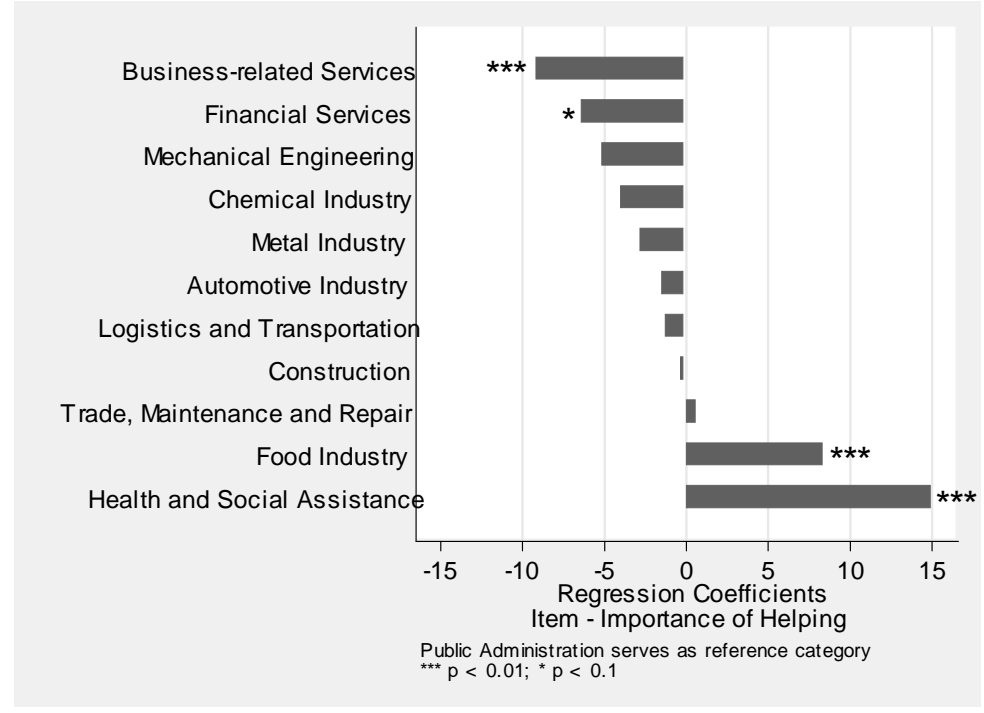

Figure A1: The fraction of cooperative employees across German industries 
All Firms

\begin{tabular}{|c|c|c|c|c|c|}
\hline \multirow[t]{2}{*}{ Dependent Variable } & \multicolumn{5}{|c|}{ "You can count on the people to cooperate" } \\
\hline & $(1)$ & $(2)$ & (3) & $(4)$ & $(5)$ \\
\hline \multirow[t]{2}{*}{ Individual PRP } & 0.0545 & 0.0153 & 0.0164 & -0.0107 & $-0.261^{* *}$ \\
\hline & $(0.138)$ & $(0.156)$ & $(0.145)$ & $(0.121)$ & $(0.116)$ \\
\hline \multirow[t]{2}{*}{ Team PRP } & $0.626^{* * *}$ & $0.672^{* * *}$ & $0.652^{* * *}$ & $0.557^{* * *}$ & $0.665^{* * *}$ \\
\hline & $(0.231)$ & $(0.222)$ & $(0.176)$ & $(0.195)$ & $(0.181)$ \\
\hline \multirow[t]{2}{*}{ Firm PRP } & 0.112 & 0.0697 & -0.134 & -0.131 & -0.143 \\
\hline & $(0.353)$ & $(0.362)$ & $(0.330)$ & $(0.308)$ & $(0.445)$ \\
\hline \multirow[t]{2}{*}{ Hierarchical Levels } & $3.346^{* * *}$ & $3.719 * * *$ & $3.787 * * *$ & $3.051^{* * *}$ & $2.505^{* *}$ \\
\hline & $(0.793)$ & $(0.788)$ & $(0.751)$ & $(0.667)$ & $(1.076)$ \\
\hline \multirow[t]{2}{*}{ Works Council } & $-3.931^{*}$ & $-4.606^{* *}$ & -3.186 & -2.047 & 0.0705 \\
\hline & $(2.311)$ & $(2.305)$ & $(2.370)$ & $(2.197)$ & $(2.987)$ \\
\hline \multirow[t]{2}{*}{ Parttime Workers } & $0.169^{* *}$ & $0.127^{*}$ & $0.132^{*}$ & 0.0917 & 0.115 \\
\hline & $(0.0773)$ & $(0.0747)$ & $(0.0718)$ & $(0.0618)$ & $(0.0894)$ \\
\hline \multirow[t]{2}{*}{ Low Wage Level } & & -4.176 & -4.975 & -2.598 & -8.164 \\
\hline & & $(3.985)$ & $(3.842)$ & $(3.012)$ & $(7.400)$ \\
\hline \multirow[t]{2}{*}{ High Wage Level } & & -0.0531 & -0.0325 & 0.229 & 2.178 \\
\hline & & $(2.144)$ & $(2.087)$ & $(1.839)$ & $(2.855)$ \\
\hline \multirow[t]{2}{*}{ Downsizing } & & & -1.871 & -0.665 & -3.258 \\
\hline & & & $(2.325)$ & $(2.193)$ & $(3.607)$ \\
\hline \multirow[t]{2}{*}{ Upsizing } & & & $6.832^{* * *}$ & $5.481^{* *}$ & $7.546^{* *}$ \\
\hline & & & $(2.443)$ & $(2.271)$ & $(3.326)$ \\
\hline \multirow[t]{2}{*}{ Job Satisfaction } & & & & $0.478 * * *$ & $0.408^{* *}$ \\
\hline & & & & $(0.110)$ & $(0.179)$ \\
\hline \multirow[t]{2}{*}{ Gender Career } & & & & & -5.246 \\
\hline & & & & & $(8.842)$ \\
\hline \multirow[t]{2}{*}{ Trainings } & & & & & -0.011 \\
\hline & & & & & $(0.028)$ \\
\hline \multirow[t]{2}{*}{ Constant } & $51.02^{* * *}$ & $51.03^{* * *}$ & $47.07 * * *$ & 12.92 & 11.37 \\
\hline & $(5.274)$ & $(5.257)$ & $(5.656)$ & $(9.220)$ & $(15.39)$ \\
\hline Observations & 281 & 257 & 257 & 257 & 145 \\
\hline$R^{2}$ & 0.238 & 0.255 & 0.294 & 0.399 & 0.396 \\
\hline
\end{tabular}

*** $\mathrm{p}<0.01,{ }^{* *} \mathrm{p}<0.05,{ }^{*} \mathrm{p}<0.1$, robust standard errors in parentheses

OLS regression: further controls: 11 industry and 2 firm size dummies

Reference category: 0-99 employee firm in the food industry

Table A2: Performance-related pay, HR policies and cooperation among workers 